\title{
LIMBAH PEMANENAN JATI DI BANYUWANGI JAWA TIMUR
}

\author{
Teak Harvesting Waste at Banyuwangi East Java \\ Juang Rata Matangaran ${ }^{1 凹}$ dan Romadoni Anggoro ${ }^{2}$ \\ ${ }^{1}$ Departemen Manajemen Hutan Fakultas Kehutanan Institut Pertanian Bogor, \\ Jalan Raya Darmaga Kampus IPB Darmaga, Bogor 16680, \\ 2Alumni Fakultas Kehutanan Institut Pertanian Bogor, email: romadoni.9@gmail.com
}

\begin{abstract}
Harvesting teak in Java always causes wood waste in the forest. The objectives of this research were to identify the shape of wood waste generated from teak harvesting activities and to determine their recovery and residual factors. The research was conducted at teak forest of Stated Owned Company (Perum Perhutani) at Banyuwangi East Java with the sampling intensity of $10 \%$ using whole tree method. Measurement of wood waste was performed at thinning and clearcutting compartment of teak stand. The result of the study showed that the shapes of wood waste consisted of broken stem, decay wood, short trimming, branch and twig , stump, and irregular wood shape. The recovery and residual factors of the teak harvesting utilization were $79.61 \%$ and $20.39 \%$, respectively. Most of the wood waste were utilized by the local community for energy sources.
\end{abstract}

Key words: Recovery factor, residual factor, teak, wood waste

\section{PENDAHULUAN}

Pemanenan hutan selalu menyisakan kayu di dalam hutan yang disebut limbah pemanenan. Penebangan berpotensi menghasilkan limbah berupa tunggak dan batang pecah banting. Pemotongan tajuk (topping), pemotongan cabang dan ranting (debranching) berpotensi menghasilkan limbah berbentuk cabang dan ranting. Sedangkan pembagian batang (bucking) berpotensi menghasilkan limbah berbentuk potongan pendek, maupun limbah kayu kayu cacat seperti limbah kayu lapuk, busuk hati/gerowong. Limbah pemanenan ternyata bermanfaat bagi masyarakat desa sekitar hutan. Masyarakat memanfaatkan limbah pemanenan sebagai komoditas perdagangan maupun sebagai bahan bakar untuk kebutuhan sendiri.

Menurut Direktorat Jenderal Kehutanan (1973) limbah kayu diartikan sebagai sisa-sisa atau bagian kayu yang dianggap tidak bernilai ekonomis lagi

Diterima: 5 Juli 2012; Disetujui: 4 September 2012

$\triangle$ Penulis korespondensi (corresponding author): jrmatangaran@yahoo.com dalam suatu proses tertentu, pada waktu dan tempat tertentu, namun mungkin masih dapat dimanfaatkan pada proses yang berbeda, pada waktu dan tempat yang berbeda pula, sedangkan Matangaran et al. (2000) menyatakan bahwa limbah pemanenan merupakan limbah mekanis yang terjadi akibat kegiatan pemanenan kayu di samping limbah alami (defect) yang tidak memenuhi persyaratan yang diinginkan.

Dewasa ini terdapat beberapa bentuk kemungkinan industri pemanfaatan limbah kayu seperti industri papan partikel, papan serat, papan blok, papan sambungan, papan laminasi, moulding, dowel, mebel, pulp dan kertas serta industri arang kayu. Limbah pemanenan juga dapat dimanfaatkan sebagai sumber energi (kayu bakar) untuk keperluan rumah tangga dan industri. Penggunaan kayu bakar di industri misalnya untuk pengasapan karet, pembuatan gula rakyat, pembakaran gamping, pembakaran batu bata, dan genteng.

Penelitian mengenai besarnya limbah sudah banyak dilakukan di hutan alam maupun hutan tanaman khususnya hutan tanaman industri. Namun penelitian untuk hutan jati perlu dilakukan mengingat limbah kayu jati yang tidak dimanfaatkan lagi oleh perhutani ternyata masih sangat diperlukan oleh 
masyarakat di sekitar hutan baik sebagai sumber energi maupun bahan kerajinan ukir kayu jati.

Penelitianinibertujuanuntuk(1)mengidentifikasi bentuk limbah kayu yang muncul dalam kegiatan pemanenan di hutan jati, (2) menghitung besarnya faktor pemanfaatan dan faktor residu (limbah) dari kegiatan pemanenan di hutan jati di Kesatuan Pemangkuan Hutan (KPH) Banyuwangi Utara Perum Perhutani Unit II Jawa Timur.

\section{METODE PENELITIAN}

\section{Lokasi, objek penelitian dan unit contoh}

Lokasi penelitian di Bagian Kesatuan Pemangkuan Hutan (BKPH) Watudodol, BKPH Ketapang, KPH Banyuwangi Utara, Perum Perhutani Unit II Jawa Timur. Objek penelitian adalah tegakan jati (Tectona grandis) dari tebang habis tahun berjalan (A2) dan tebang penjarangan (E).

Limbah dalam penelitian ini adalah limbah yang terjadi akibat pemanenan hutan jati, khususnya limbah penebangan di petak tebang. Dalam penelitian ini yang dimaksud dengan limbah pemanenan adalah bagian pohon yang tidak dimanfaatkan oleh pola pemanfaatan yang berlaku pada saat ini dan dibiarkan di dalam hutan.

Penentuan petak contoh dilakukan dengan metode purposive yaitu mengikuti kegiatan yang sedang berlangsung di lapangan. Pohon contoh dipilih tersebar mewakili kelas umur (KU). Jumlah pohon contoh dihitung berdasarkan daftar klem petak tebang. Intensitas sampling yang ditetapkan dalam penelitian ini adalah $10 \%$. Jumlah pohon yang ditebang dan jumlah pohon sampel dalam blok tebang yang diteliti tercantum pada Tabel 1 .

\section{Perhitungan volume limbah}

Metode pengukuran yang digunakan adalah metode pohon penuh (whole tree method) (Budiaman, 2000). Metode ini dapat menentukan jumlah keseluruhan sortimen kayu bulat dan jenis kayu bulat dari setiap individu pohon. Untuk bentuk limbah yang tidak dapat diukur langsung dalam kubikasi maka digunakan cara stapel meter (sm) dan dikonversi ke satuan $\mathrm{m}^{3}$ (Coto, 1979).

Pengukuran volume kayu pertukangan dan pengukuran volume limbah dilakukan sebagai berikut:

1. Kayu Pertukangan

Pengukuran volume kayu pertukangan dihitung dengan menjumlahkan volume seksi-seksi batang (sortimen) dari pohon yang bersangkutan. Penghitungan volume per seksi dilakukan menggunakan metode yang berlaku di Perum Perhutani.

2. Limbah Kayu Pecah, Kayu Lapuk, Sortimen Pendek dan Tunggak

Pengukuran dilakukan dengan menghitung diameter rata-rata pangkal dan ujung. Khusus untuk tunggak, diameter yang digunakan dalam perhitungan adalah diameter ujung. Panjang diukur dari jarak terpendek antara pangkal dan ujung yang sejajar dengan panjang sumbu pohon. Volume sortimen dihitung menggunakan rumus Smallian.

3. Limbah Cabang dan Ranting

Penghitungan volume limbah cabang dan ranting dilakukan dengan pendekatan satuan stapel meter. Limbah berupa cabang dan ranting dikumpulkan dan ditumpuk tiap-tiap pohon. Volume kayu limbah dalam satuan sm dihitung dengan mengalikan panjang, lebar dan tinggi tumpukan. Satuan sm kemudian dikonversi ke dalam satuan $\mathrm{m}^{3}$ menggunakan pendekatan menurut Coto (1979), dimana $1 \mathrm{sm}$ kayu limbah pemanenan setara dengan $0,38 \mathrm{~m}^{3}$ kayu bulat.

4. Limbah dengan Bentuk Tak Beraturan

Diameter kayu tak beraturan (kayu pakah) dihitung dari rata-rata diameter pangkal sesuai metode pengukuran untukkayu-kayu pakah di Perum Perhutani. Diameter kayu tidak silindris dihitung dari rata-rata diameter pangkal dan diameter ujungnya. Panjang kayu bengkok dihitung dari jarak terpendek antara pangkal dan ujung sortimen. Volume kayu dengan busuk hati/hati rapuh/gerowong dihitung dengan mengurangkan volume kayu total dengan volume cacat tersebut.

Tabel 1. Penentuan unit contoh

\begin{tabular}{ccccc}
\hline No. & Petak/blok & Jenis Tebangan/ KU & Jumlah Pohon Ditebang & Jumlah Pohon Sampel \\
\hline 1 & 67 // III & E KU II & 318 & 32 \\
2 & 77 i/ VIII & E KU III & 315 & 32 \\
3 & $39 \mathrm{~b} /$ II & E KU IV & 390 & 39 \\
4 & $52 \mathrm{~b} / \mathrm{VII}$ & A2 KU V & 392 & 40
\end{tabular}

Keterangan: E (tebang penjarangan), A2 (tebang habis tahun berjalan), KU (Kelas Umur) 


\section{Faktor pemanfaatan dan faktor residu}

Faktor pemanfaatan (recovery rate) dan faktor residu dihitung dengan menggunakan persamaan berikut (Budiaman, 2000):

$f m=\frac{V m}{V t} \times 100 \%$

keterangan:

$\mathrm{fm}=$ faktor pemanfaatan $(\%)$

$\mathrm{Vm}=$ volume kayu yang dimanfaatkan $\left(\mathrm{m}^{3}\right)$. Volume kayu yang dimanfaatkan adalah volume kayu pertukangan yang diproduksi. Pengukuran volume kayu pertukangan dihitung dengan menjumlahkan volume seksi-seksi batang (sortimen).

$V t=$ volume total pohon (m3). Volume total pohon diperoleh dengan menjumlahkan volume kayu yang dimanfaatkan dengan volume limbah dari masing-masing pohon. Perhitungan volume pohon menggunakan rumus Smallian.

$f r=\frac{V r}{V t} \times 100 \%$

keterangan:

fr $=$ faktor residu (\%)

$V r=$ volume limbah $\left(\mathrm{m}^{3}\right)$ adalah jumlah volume semua bentuk limbah yang dihasilkan dari masing-masing pohon.

$V t=$ volume total pohon $\left(\mathrm{m}^{3}\right)$

\section{HASIL DAN PEMBAHASAN}

\section{Bentuk limbah pemanenan jati}

Limbah dapat berasal dari bagian batang utama, batang atas, cabang dan ranting atau berasal dari tunggak. Limbah pemanenan kemudian diklasifikasikan dalam beberapa bentuk, yaitu:

1. Kayu pecah adalah sortimen kayu bulat yang masuk dalam target produksi sebagai kayu perkakas, namun ditinggalkan karena pecah saat penebangan. Sortimen ini memiliki panjang $40 \mathrm{~cm}$ dan diameter $10 \mathrm{~cm}$.

2. Kayu lapuk adalah sortimen kayu bulat kayu bulat yang masuk dalam target produksi sebagai kayu perkakas, namun ditinggalkan karena lapuk. Sortimen ini memiliki panjang $40 \mathrm{~cm}$ dan diameter $10 \mathrm{~cm}$.

3. Potongan pendek berupa kayu bulat sisa pembagian batang, sisa keprasan dan banir. Limbah bentuk ini dibatasi panjang $40 \mathrm{~cm}$ dan diameter $10 \mathrm{~cm}$.

4. Cabang dan ranting adalah komponen tajuk yang berada di atas cabang pertama. Cabang dan ranting yang diukur dalam penelitian ini dibatasi sampai diameter terkecil $4 \mathrm{~cm}$.

5. Tunggak adalah bagian bawah pohon yang berada di bawah takik rebah dan takik balas. Tingginya bervariasi tergantung ketinggian takik balas.

6. Kayu tak beraturan adalah kayu pakah (madopang), kayu bengkok, kayu tidak silindris dan kayu dengan busuk hati/gerowong/hati rapuh yang parah (tidak memenuhi syarat minimal untuk kayu bahan parket).

\section{Volume limbah jati}

Limbah pemanenan kayu jati diklasifikasikan menjadi enam bentuk yaitu; limbah kayu pecah, kayu lapuk, potongan pendek, cabang dan ranting, limbah tunggak, dan limbah kayu tak beraturan. Limbah pemanenan kemudian dihitung volumenya berdasarkan pengelompokannya masing-masing. Volume masing-masing bentuk limbah dijelaskan dalam Tabel 2.

Rata-rata total volume limbah meningkat seiring meningkatnya kelas umur. Volume limbah rata-rata/pohon KU II, KU III, KU IV dan KU V masing-masing berturut-turut: 0,$011 ; 0,075 ; 0,179$ dan $0,206 \mathrm{~m}^{3}$. Jumlah limbah tiap pohon meningkat seiring meningkatnya kelas umur. Hal ini dapat

Tabel 2. Volume limbah pemanenan

\begin{tabular}{|c|c|c|c|c|c|c|c|c|c|}
\hline \multirow[b]{2}{*}{ KU } & \multirow{2}{*}{$\begin{array}{l}\text { Jumlah } \\
\text { Pohon } \\
\text { Contoh }\end{array}$} & \multicolumn{6}{|c|}{ Volume Limbah $\left(\mathrm{m}^{3}\right)$} & \multirow{2}{*}{$\begin{array}{c}\text { Total } \\
\text { Volume } \\
\text { Limbah } \\
\left(\mathrm{m}^{3}\right)\end{array}$} & \multirow{2}{*}{$\begin{array}{c}\text { Total } \\
\text { Volume } \\
\text { limbah }\left(\mathrm{m}^{3}\right. \\
\left.\text { pohon }{ }^{-1}\right)\end{array}$} \\
\hline & & $\begin{array}{l}\text { Kayu } \\
\text { Pecah }\end{array}$ & $\begin{array}{l}\text { Kayu } \\
\text { Lapuk }\end{array}$ & $\begin{array}{c}\text { Potongan } \\
\text { Pendek }\end{array}$ & $\begin{array}{c}\text { Cabang \& } \\
\text { Ranting }\end{array}$ & Tung gak & $\begin{array}{l}\text { Kayu Tak } \\
\text { Beraturan }\end{array}$ & & \\
\hline$\|$ & 32 & 0,000 & 0,002 & 0,015 & 0,315 & 0,017 & 0,017 & 0,366 & 0,011 \\
\hline III & 32 & 0,033 & 0,013 & 0,004 & 2,203 & 0,072 & 0,061 & 2,386 & 0,075 \\
\hline IV & 39 & 0,283 & 0,054 & 0,079 & 6,266 & 0,227 & 0,055 & 6,964 & 0,179 \\
\hline V & 40 & 0,136 & 0,005 & 0,021 & 8,001 & 0,064 & 0,019 & 8,245 & 0,206 \\
\hline
\end{tabular}


Tabel 3. Persentase (\%) bentuk limbah pemanenan jati terhadap total volume limbah jati

\begin{tabular}{|c|c|c|c|c|c|c|c|c|c|}
\hline \multirow[b]{2}{*}{ No. } & \multirow[b]{2}{*}{$\mathrm{KU}$} & \multirow{2}{*}{$\begin{array}{l}\text { Jumlah } \\
\text { Pohon } \\
\text { Contoh }\end{array}$} & \multicolumn{6}{|c|}{ Bentuk Limbah (\%) } & \multirow{2}{*}{$\begin{array}{c}\text { Jumlah } \\
(\%)\end{array}$} \\
\hline & & & $\begin{array}{l}\text { Kayu } \\
\text { Pecah }\end{array}$ & $\begin{array}{l}\text { Kayu } \\
\text { Lapuk }\end{array}$ & $\begin{array}{l}\text { Potongan } \\
\text { Pendek }\end{array}$ & $\begin{array}{c}\text { Cabang \& } \\
\text { Ranting }\end{array}$ & Tunggak & $\begin{array}{l}\text { Kayu Tak } \\
\text { Beraturan }\end{array}$ & \\
\hline 1 & $\|$ & 32 & 0,00 & 0,52 & 4,04 & 86,05 & 4,63 & 4,76 & 100 \\
\hline 2 & III & 32 & 1,37 & 0,56 & 0,17 & 92,36 & 3,00 & 2,55 & 100 \\
\hline 3 & IV & 39 & 4,06 & 0,78 & 1,14 & 89,98 & 3,26 & 0,78 & 100 \\
\hline 4 & V & 40 & 1,65 & 0,06 & 0,26 & 97,03 & 0,78 & 0,23 & 100 \\
\hline Rata-rata & & & 1,77 & 0,48 & 1,40 & 91,36 & 2,91 & 2,08 & \\
\hline
\end{tabular}

Tabel 4. Faktor pemanfaatan menurut kelas umur

\begin{tabular}{cccccc}
\hline Kelas Umur & $\begin{array}{c}\text { Jumlah Pohon } \\
\text { Contoh }\end{array}$ & $\begin{array}{c}\text { Volume Produksi } \\
\left(\mathrm{m}^{3}\right)\end{array}$ & $\begin{array}{c}\text { Total Volume Kayu } \\
\left(\mathrm{m}^{3}\right)\end{array}$ & $\begin{array}{c}\text { Faktor } \\
\text { Pemanfaatan }(\%)\end{array}$ & $\begin{array}{c}\text { Faktor Residu } \\
(\text { limbah) }(\%)\end{array}$ \\
\hline II & 32 & 1,693 & 2,059 & 82,23 & 17,77 \\
III & 32 & 5,957 & 7,643 & 77,94 & 22,06 \\
IV & 39 & 27,844 & 34,808 & 79,99 & 20,01 \\
V & 40 & 29,736 & 37,981 & 78,29 & 21,71 \\
\hline Rata-rata & & & 79,61 & 20,39 \\
\hline
\end{tabular}

dimengerti karena rata-rata diameter pohon KU V lebih besar dari KU yang lebih muda. Untuk limbah berupa tunggak, dengan tinggi tunggak yang sama tentu volume tunggak KU V lebih besar dari volume tunggak KU IV karena diameter pohon KU V lebih besar. Untuk limbah berbentuk cabang dan ranting, pohon-pohon KU tua tentu memiliki tajuk yang lebih besar daripada KU yang lebih muda. Sedangkan limbah berupa cabang dan ranting dibatasi pada kayu dengan diameter $4 \mathrm{~cm}$. Limbah dengan batasan demikian pada tajuk yang lebih besar tentu lebih banyak daripada pada tajuk yang lebih kecil.

Persentase bentuk limbah terhadap total volume limbah menunjukkan bentuk limbah cabang dan ranting adalah bentuk limbah terbanyak dengan persentase sebesar $91,36 \%$. Untuk masing-masing kelas umur bentuk limbah di luar cabang dan ranting bernilai paling besar $4,76 \%$ yaitu pada bentuk limbah kayu tak beraturan pada KU II. Prosentase volume berdasarkan bentuk limbah dijelaskan dalam Tabel 3.

\section{Faktor pemanfaatan dan faktor residu jati}

Faktor pemanfaatan (recovery rate) adalah proporsi volume kayu yang dimanfaatkan terhadap total volume pohon. Faktor pemanfaatan dapat menggambarkan efektifitas kegiatan pemanenan. Kegiatan pemanenan relatif lebih efektif pada petak dengan faktor pemanfaatan yang lebih besar. Faktor pemanfaatan berdasarkan kelas umur disajikan dalam Tabel 4.
Besarnya limbah dipengaruhi oleh beberapa hal yaitu: kebijakan perusahaan, topografi, kerapatan tegakan, sistem upah, keterampilan tenaga kerja dan pengawasan (Dulsalam, 1995). Secara umum faktor pemanfaatan pada pemanenan KU II, KU IV dan KU V tidak jauh berbeda dengan nilai rata-rata $79,61 \%$. Sedangkan faktor residu yang merupakan limbah adalah 20,39 \%. Pengamatan di lapangan menunjukkan limbah yang tidak dimanfaatkan oleh Perum Perhutani dimanfaatkan oleh masyarakat di sekitar hutan umumnya sebagai sumber energi (kayu bakar) yang dipakai sendiri maupun dijual kembali. Hasil penelitian di beberapa negara lain seperti Finlandia dan Inggris, menunjukkan bahwa limbah pemanenan hutan telah diolah menjadi serpih kayu (chip) yang selanjutnya dapat digunakan dan diproses sebagai bahan baku bioenergi (Hall, 2000; Hermisaari et al., 2011).

Penelitian lainnya tentang faktor residu dan faktor pemanfaatan juga telah banyak dilakukan pada hutan alam. Simarmata \& Sastrodimejo (1980) menunjukkan faktor residu sebesar $23,6 \%$ untuk 24 perusahaan Hak Pengusahaan Hutan. Penelitian Sianturi (1982) menunjukkan hasil sebesar 20,4 $\%$ untuk 8 perusahaan Hak Pengusahan Hutan di Kalimantan Tengah dan Kalimantan Selatan. Budiaman (2000) menghasilkan nilai faktor residu sebesar 39,53 \% di Jambi. Sedangkan Sianturi et al. (1984) menunjukkan faktor pemanfaatan kayu di hutan alam Pulau Laut sebesar $80 \%$. 


\section{KESIMPULAN}

Bentuk limbah pemaneman jati adalah kayu pecah, kayu lapuk, potongan pendek serta cabang dan ranting, tunggak, kayu tak beraturan. Semakin tinggi kelas umur pohon jati semakin banyak limbah yang dihasilkan dalam pemanenannya. Besarnya tingkat pemanfaatan kayu adalah $79,61 \%$ dan limbah sebesar 20,39\%.

\section{UCAPAN TERIMA KASIH}

Terima kasih kepada Administratur Perum Pehutani KPH Banyuwangi Utara yang telah membantu terlaksananya penelitian ini.

\section{DAFTAR PUSTAKA}

Budiaman, A. 2000. Kuantifikasi kayu bulat kecil limbah pemanenan pada pengusahaan hutan alam. Jurnal Teknologi Hasil Hutan Fakultas Kehutanan IPB 13 (2): 34-43.

Coto, Z. 1979. Teknik efisiensi penggunaan enersi kayu bakar. Di dalam: Peningkatan Penyediaan dan Pemanfaatan Kayu sebagai Sumber Energi. Prosiding Dalam Rangka Hari Pulang Kandang Alumni Fakultas Kehutanan IPB; Bogor, 8-9 September 1979. Bogor: Fakultas Kehutanan IPB. HIm 86-90.

Direktorat Jenderal Kehutanan. 1973. Penelitian logging waste: Logging waste dan kemungkinan kemungkinan pemanfaatannya di Jawa dan Kalimantan Timur. Bogor: Fakultas Kehutanan IPB.
Dulsalam. 1995. Usaha untuk meminimalisasi limbah eksploitasi dalam rangka peningkatan nilai produksi. Makalah Penunjang dalam Ekspose Penelitian Hasil Hutan. Bogor: Lembaga Penelitian Hasil Hutan.

Hall, P. 2000. Bioenergy fuel from stem-to-log processing waste using conventional forest harvesting system. New Zealand Journal of Forestry Science, 30 (1). 108113.

Helmisaari, HS, K.H. Hansen, S. Jacobson, M. Kukkola, J. Luiro, A. Saarsalmi and P. Tamminen. 2011. "Logging residu removal after thinning in Nordic boreal forests:longterm impact on the growth". Forest Ecology and Management,261. 19191927.

Matangaran, J.R., L.T. Togar, U.K. Tjetjep dan E.Y. Yovi. 2000. Studi pemanfaatan limbah pembalakan untuk bahan baku industri dalam rangka pengembangan dan pemasaran hasil hutan. Laporan Akhir. Direktorat Jenderal Pengelolaan Hutan Produksi bekerjasama dengan Fakultas Kehutanan IPB. Bogor.

Perum Perhutani. 2006. Keputusan Kepala Perum Perhutani Unit II Jawa Timur Nomor 1168/KPTS/II/2005 tentang Petunjuk Pelaksanaan Pembagian Batang Kayu Bundar Jati. Surabaya: Perum Perhutani Unit II Jawa Timur.

Sianturi, A. 1982. Faktor Eksploitasi di Hutan Alam Dipterokarpa Pulau Laut, Kalimantan Selatan [Tesis]. Bogor: Institut Pertanian Bogor, Program Pascasarjana.

Sianturi, A, I. Soerianegara, R.S. Suparto dan S. Manan. 1984. "Faktor eksploitasi di hutan alam dipterokarpa pulau laut". Jurnal Penelitian Hasil Hutan, 1 (1). 1-10.

Simarmata, S. R. dan S. Sastrodimedjo. 1980. Limbah eksploitasi pada beberapa perusahaan pengusahaan hutan di Indonesia Bagian 2. Laporan No. 149. Bogor: Lembaga Penelitian Hasil Hutan. 